\title{
SIMULATION OF MANAGEMENT ENHANCEMENT SCENARIOS FOR THE JSC LATVIAN STATE FORESTS
}

Rolands FELDMANIS, Faculty of Economics and Social Development, Latvia University of Life Sciences and Technologies, 18 Svetes street, Jelgava, LV-3001, Latvia, rolands.feldmanis@ gmail.com (corresponding author)

Irina PILVERE, Faculty of Economics and Social Development, Latvia University of Life Sciences and Technologies, 18 Svetes street, Jelgava, LV-3001, Latvia, irina pilvere@1lu.lv

The expansion of global economy and the rise of living standards are set to force the world's consumption of raw material to nearly double by 2060 , thus consumption of wood resources is forecasted to increase more than twofold. In Latvia, forests cover $52 \%$ of the total area. The total forest area in Latvia has continued to grow since the beginning of the $20^{\text {th }}$ century - in 1923 the forests covered only $27 \%$ of the country's area; accordingly, the question is whether the value of forests continues to grow proportionally. One of the criteria for determining the value of forest is forest capital. A higher economic value of forest reflects the forest's capability to produce more wood, and this allows generating higher revenues from forestry. It is the value of plantations of certain tree species as well as the quality of wood produced that increase the price of wood and consequently result in higher revenues.

The largest supplier of wood in Latvia is the state-owned joint stock company Latvian State Forests (JSC LSF), which managed 1.6 million hectares of forestland in 2018. In 2018, 12.8 million cubic metres of roundwood were harvested in Latvia, of which 6 million cubic metres were harvested by the JSC LSF. Therefore, the research aims to design and assess potential scenarios of increasing the value of forest capital for the JSC LSF. The authors simulated potential scenarios for the JSC LSF in order to identify changes to be made in the current forest management pattern with the aim of increasing the value of forest capital. A higher value of forest capital would also mean greater public attention to the future use of existing resources. Calculations of the economic value of forests were carried out to identify necessary changes to be made in the management of state-owned forests in Latvia and to compare several management enhancement scenarios. The potential scenarios were assessed by five qualified experts, academics, representatives of business and public administration by employing the Analytic Hierarchy Process (AHP). The experts rated the possible scenarios for enhancing forest management relatively equally, giving slightly higher ratings to the potential scenario of quotation of the national forest management company on the stock exchange. The value of forest capital was calculated for each of the potential scenarios using the most commonly used net present value method (NPV). It was concluded that the potential scenario of lowering the diameter threshold for felling trees by two centimetres would lead to the greatest increase in the value of forest capital.

Keywords: forest value, analytic hierarchy process, scenarios.

\section{INTRODUCTION}

The Organisation for Economic Co-operation and Development (OECD) (2018a) reports that world's consumption of wood will double by 2060. The European Union (EU) has close to 182 million hectares of forests covering $43 \%$ of its land area, and these forest areas are one of Europe's most important renewable resources (European Commission, 2019). Moreover, European forests are increasing in area and growing stock and age (e.g. in the EU, over $90 \%$ of the raw wood processed into materials and products each year by the EU's forest-based industries comes from EU forests...) (Liaison Unit Bratislava, 2018).

In Latvia, forest is one of the most important resources for the development of rural regions and provides a living for more than 80000 people who work in various related sectors. Since the restoration of Latvia's independence in 1991, the forest area in the country has increased in a stable way - by around 60000 hectares a year. The result of this is that $52 \%$ of Latvia's area was covered by the forest in 2010, with a total area of 3.354 million hectares. Latvia has the fourth highest forest cover among the EU Member States, surpassed only by Finland (77\%), Sweden (76\%) and Slovenia (63\%) (Bekeris, 2011). In Latvia, the forest industry accounted for $4.8 \%$ of the total value added of the economy in 2017. The JSC LSF contributed to $47 \%$ of the total volume logged and made a significant effect on the national economy (Ministry of Agriculture, 2015). This has led the authors to develop a number of potential scenarios for the JSC LSF through simulating changes in key forestry-related factors and amendments to the relevant legal framework in Latvia.

In Latvia, approximately half of the forest area is in state ownership and use, while the second half is owned and used by natural and legal persons (Ministry of Agriculture, 2015). According to Decision No. 453 of the Cabinet of the Republic of Latvia of 24 September 1999 "On the Establishment of the State Joint Stock Company Latvian State Forests", the forests owned by the State are managed by the $100 \%$-state-owned JSC LSF founded in 1999. The goal of the company is to manage state-owned forests in a sustainable way (i.e. in an economically viable, environmentally friendly and socially responsible way). The JSC LSF was also the largest supplier of roundwood in Latvia, managing 1.63 million hectares of land in 2018, including 1.60 million hectares of forestland, of which 1.41 million hectares were worth EUR 2.6 billion (JSC LSF, 2018). In 2018, 12.8 million cubic metres of roundwood were harvested in Latvia, of which 6 million cubic metres were supplied by the JSC LSF (State Forest Service, 2018).

Copyright (C) 2019 The Authors. Published by Vytautas Magnus University. This is an open-access article distributed under the terms of the Creative Commons Attribution License (CC-BY 4.0), which permits unrestricted use, distribution, and reproduction in any medium, provided the original author and source are credited. 
In 2018, the largest ownership change transactions with forestland in the country's history were made. Approximately 200 thousand hectares of forestland changed their owners. The largest transaction was made by Bervigskog selling 111 thousand hectares of forestland for EUR 324 million, which was almost EUR 3000 ha $^{-1}$ (Södra, 2018). The second largest transaction was made by Foran Real Estate that sold around 50 thousand hectares of forestland; the sum was not disclosed publicly. As a result of these transactions, Scandinavian companies with long traditions in forestry and accumulated capital acquired the forestlands in Latvia. Forestland properties in Latvia are fragmented, and $51.7 \%$ of the forests are owned by individuals whose forestland properties are less than 50 hectares. In view of the fact that the cost of purchasing forestland, regardless of the number of hectares to be purchased, is the same, the buyer could pay a premium for the opportunity of acquiring more forestland at once. However, the interest in buying forestland from foreign investors could be increased in the future if the diameter threshold or the age threshold for felling trees is lowered in Latvia, which would also increase the value of forest capital. Consequently, there could also be an increased interest in the state-owned 1.4 million ha of forestland (State Forest Service, 2018). The current valuation of national forests is based on the calculations done by the JSC LSF; the current value equals EUR 2000 ha $^{-1}$.

One of the most important factors affecting forest-sector enterprises in Latvia, which is governed by the relevant legal framework and which determines the value of forest, is forest management limitations, especially the diameter or age thresholds for felling. A methodology for analysis of such limitations was designed by a German scientist, M.Faustman (1849), who suggested calculating the value of forest by taking into account the land area used to grow the forest. Similar forest valuation methods were described a little later by M.R.Presler (1860). The methodology designed by M.Faustman was enhanced by B.Ohlin (1921) and P.Samuelson (1976). One of the disadvantages of the methodology for forest valuation that was developed by M.Faustman M.R.Presler - B.Ohlin was an assumption that the forest rotation period for any species was the same, which also sets the same felling age and diameter. However, a solution was provided by G.A.Navarro (2003) who analysed alternatives to forestland use in the future. In Latvia, the transformation of forestland into another land use is limited or a payment on alternative forestland uses is imposed, thereby violating the assumption about a free capital and land market. Several scientists have used M.Faustman's methodology, setting an optimal rotation period to maximize the net present value of forestland for an endless period (Buongiorno, 2001, Jacobsen et al., 2006 and 2013). Taking into consideration M.Faustman's definition, the methodology was further enhanced by J.Jacobsen et al. (2016) in relation to how to maximise revenue.

The overall aim of the present research is to design and assess potential scenarios of increasing the value of forest capital for the JSC LSF.

To achieve the aim, the following specific research tasks are defined: 1) to design and assess potential scenarios for the JSC LSF development; 2) to calculate NPV for the selected scenarios for Latvia.

The research results are important for the growth of the economy of Latvia, as the forest industry significantly contributes to the national economy, and generating more revenue gives an opportunity for increasing the value of capital of state-owned forests, according to the relevant scenario. A higher value of forest capital would also increase the value of a cross-national indicator - gross domestic product (GDP) per capita. Increasing the value of forest capital by $1 \%$ could increase GDP per capita by EUR 13 (CSB, 2019 and the authors' calculations).

\section{METHODOLOGY AND DATA}

To achieve the research aim - to identify scenarios for the management of state-owned forests - and perform the subordinate research tasks, the simulation of forest management was divided into two stages to assess the opportunities provided by: 1) amendments to the Law on Forests of the Republic of Latvia (2000) regarding lowering the age and diameter thresholds for felling trees; 2) a decision on transferring the management of state-owned forests to private entities (Figure 1).

In Latvia, the Law on Forests (2000) restricts logging by setting the age and diameter thresholds for felling, which in its turn limits the wood volume to be logged. Lowering the age and diameter thresholds gives an opportunity to increase the volume to be logged (Liepa, 2006). As the age and diameter of trees increase, according to the tree growth model developed by a professor of Latvia University of Life Sciences and Technologies (2006), the growth of trees decelerates. For example, the fastest growth period for coniferous trees is approximately up to the age of twenty years. A rapid slowdown in tree growth and, therefore, a slowdown in increase in growing stock and carbon dioxide sequestration occurs at the age of fifty-sixty, depending on the tree species. For this reason, the authors designed and simulated scenarios for the value of forest capital if changing the diameter threshold as well as the age threshold, which would decrease the forest rotation period. A shorter forest rotation period means a possibility to produce more wood, which in its turn increases sales revenues and the value of forest capital.

The next potential scenario to be simulated is full or partial transfer of management of state-owned forests to private businesses. The OECD (2018b) report Privatisation and the Broadening of Ownership of State-Owned Enterprises stresses that "privatisation revenues have risen from around USD 110 billion in 2008 to USD 266 billion in 2016. Governments, already under pressure to raise fiscal revenues and reassess the role of the state in the commercial economy, have increasingly chosen to take advantage of opportunities for privatisation that have emerged with internationalisation, market de-regulation and technological progress".

The rate of return on private capital exceeds that on public capital. According to the world's largest stock exchanges, a ROE (return on equity for investment in stocks) is, on average, in the range of 6-8\% (authors' calculations based on the S\&P 500, Nasdaq 100 indexes for the period 1950-2018). A discount rate of $4.58 \%$ was used to identify the value of forests managed by the JSC LSF (JSC LSF, 2018). Accordingly, a higher discount rate in the range of 6-8\% should be used for the scenario of full or partial transfer of management of state-owned forests to private businesses. 


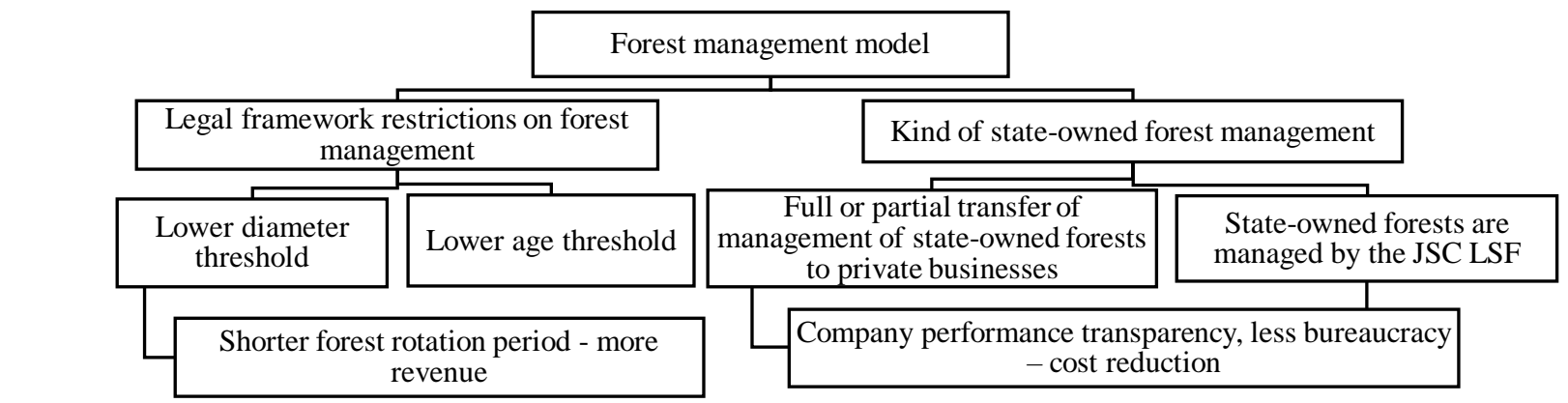

Source: authors' construction

Figure 1. Scheme for assessing the scenarios for forest management in Latvia

To identify the best possible scenario for forest management, the authors employed a multi-criteria decision-making method - the Analytical Hierarchy Process (Saaty, 1990). According to the AHP, five highly qualified experts representing forest management companies from the public and private sectors as well as the Ministry of Finance and a national research institution were surveyed. The authors created a hierarchy that included a problem at the first level; at the second level, the experts rated the economic, social and ecological factors of achieving the goal, while the significance of the criteria affecting each factor was determined at the third level.

At the fourth level, the experts were offered three potential scenarios: lowering the diameter threshold for felling trees, lowering the age threshold for felling trees or full or partial transfer of the state-owed forest management company to private ownership (Figure 2).

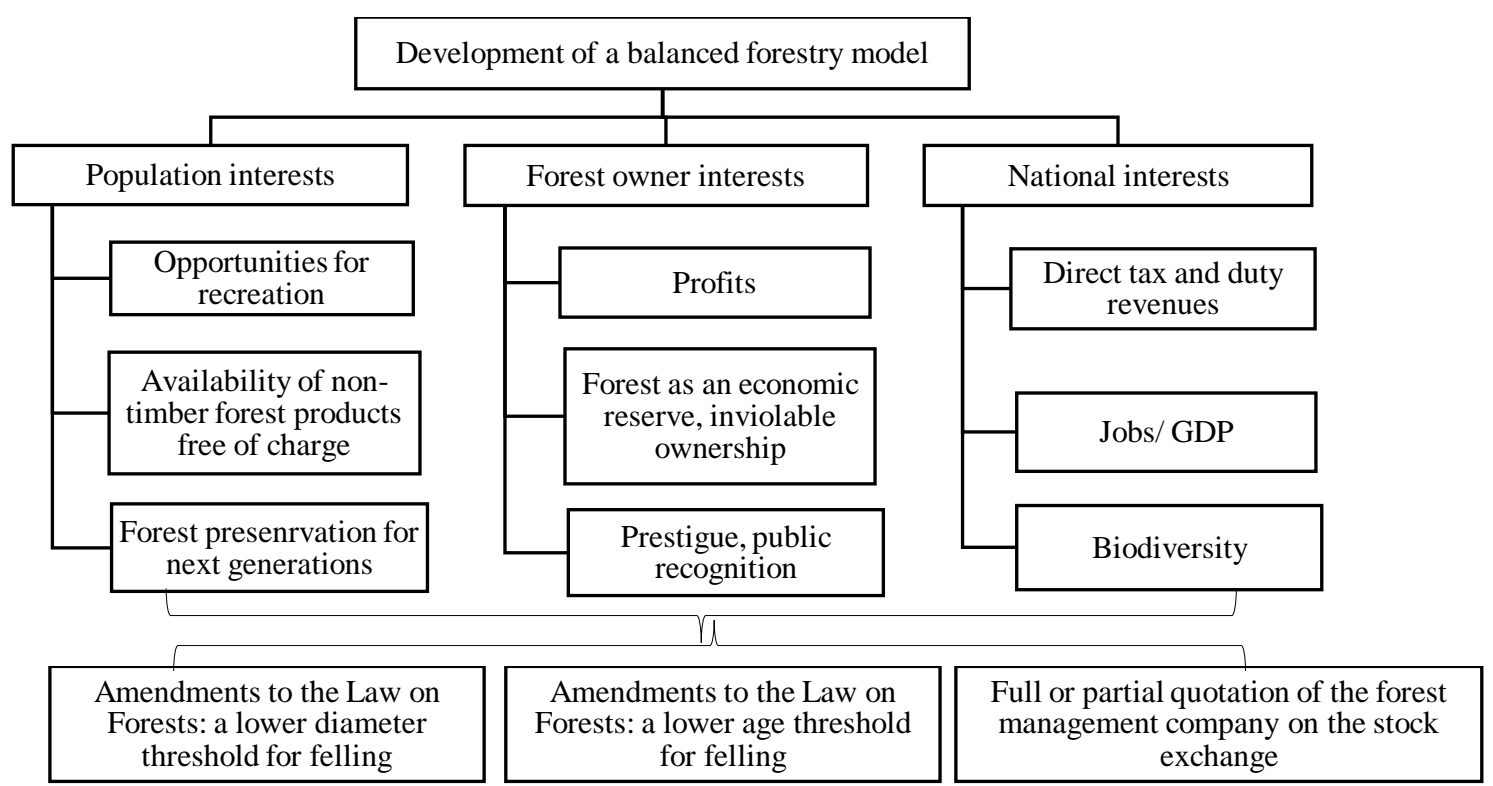

Source: authors' construction

Figure 2 Hierarchy of potential scenarios for the balanced forestry model

The authors processed the experts' ratings of the following three potential scenarios:

1) lowering the age threshold for felling trees by ten years;

2) lowering the diameter threshold for felling trees by two centimetres;

3) full or partial quotation of the forest management company on the stock exchange, which means transferring the management of forests to private businesses.

The first two scenarios involve making amendments to the relevant legal framework, thus decreasing the forest rotation period and, in its turn, increasing wood growth and production and, consequently, making a larger contribution to both the national economy and forest owners.

More revenue earned by the largest state-owned company could allow increasing investment in forest infrastructure as well as an increase in the value of forest capital would contribute to the development of the forest industry. Population interests involve increasing carbon dioxide sequestration by forests as a result of faster forest growth. However, younger trees would perhaps give less aesthetic enjoyment. The aesthetic of forests and biodiversity could be partly increased by setting new nature reserves or increasing the area of the existing ones or by increasing areas with restricted economic activity. The third scenario represents the insight into necessary structural changes in forest management in Latvia given by the experts.

To calculate the effect of each scenario simulated on the national economy and identify the quality of forests based on market prices (value of forest capital), the authors employed the net present value method. To simulate a discounted cash flow, the authors used a forest management model developed by company Remsoft in cooperation with the JSC LSF. The model allows identifying the composition and quantity of wood supply throughout the maximum tree lifecycle of 120 years (Liepa, 2018). To 
broaden the spectrum of the research results, the value of forest capital for the simulated scenarios was calculated at different discount rates, with an increment of two percentage points.

\section{RESEARCH RESULTS}

\section{Assessment of the potential scenarios for enhancement of forest management in Latvia}

Experts evaluated population interests to be ahead of forest management company and national interests, by assigning average score of 0.45 , while forest management company interests came second in their opinion with score 0.32 , and lowest score of 0.23 was assigned to state interests. An in-depth analysis revealed that experts assessed that from population interests the prevailing was forest maintenance for future generations, in forest management company most important factor was profitability possibilities, and from national interests most important factor was number of work places/ GDP.

When assessing scenarios, from the perspective of "population interests", the experts gave almost equal rating, e.g. the highest rating was given to the scenario of lowering the age threshold for felling trees $(0.16)$, followed by the scenario of lowering the diameter threshold for felling trees $(0.15)$ and the scenario of full or partial transfer of the stateowned forest management company to private businesses $(0.15)$.

Transferring the management of state-owned forests to private businesses was justified by the need to make the management of this state-owned property more transparent. From the perspective of "forest owner interests", the experts gave the highest rating to the scenario of full or partial privatisation of the forest management company (0.12) followed by the scenario lowering the diameter threshold (0.11). A rating of 0.08 given to the scenario of lowering the age threshold could be explained by a demand correction - smaller diameter roundwood was in high demand in the market; a lower diameter threshold for felling trees could be economically beneficial if the forest rotation period is made shorter. However, the transfer of forest management activities to private businesses is justified by an opportunity for more efficient management, as well as lower prices for procurement. From the perspective of "national interests", lowering the age threshold for felling trees (0.09) was the most important scenario, while the scenarios of transfer of the state-owed forest management company to private ownership (0.08) and lowering the diameter threshold for felling trees were rated almost equally (0.07).

The strategic goal matrix of the JSC LSF encompasses its key financial goals, earnings (EBITDA - earnings before interest, taxes, depreciation and amortization), dividends paid and the value of forest capital. In 2018, the EBITDA reached EUR 141 million, 70\% of the after-tax profit earned was paid in dividends and the value of forest capital totalled EUR 2.6 billion. The after-tax profit reported in the annual financial statement of the JSC LSF was EUR 110 million. This allows calculating a profit margin - profit divided by the value of forest capital -, which was $4.2 \%$. The discount rate for calculating the value of forest capital was $0.4 \%$-points higher, at $4.6 \%$. This indicates that the cost of capital is higher than the profit margin earned. This fact raises a question about opportunities for increasing the value of forest capital.

The strategic goal matrix of the JSC LSF includes also nonfinancial goals, among which being a reliable and predictable partner is the most important one pertaining to the national economy. The nonfinancial performance of the JSC LSF involves supplying a certain annual quantity of wood products over a twenty-year cycle. In 2018, it supplied 2.9 million cubic meters of coniferous roundwood and 0.4 million cubic meters of birch veneer logs. In the experts' opinion, the proportion of trees at felling age is high in state-owned forests, even though the experts also noted that the volume to be logged could be increased by at least $5 \%$ if lowering the diameter threshold or the age threshold for felling trees. However, in view of global climate change and the need to increase the growth of forest, the experts favoured lowering the diameter threshold for felling trees. The representatives of the research institution and national institutions considered lowering the diameter threshold and the age threshold for felling trees to be equally important. In contrast, the business professionals and the experts of the JSC LSF preferred lowering the diameter threshold for felling trees, which was determined by the need of the wood-processing industry for smaller-diameter roundwood. The experts of the JSC LSF also referred to global climate change - as the average temperature rises, the growth of trees increases, reaching the diameter threshold for felling trees earlier -, which, in its turn, makes the forest rotation period shorter. At the same time, the experts pointed to an opportunity to fully or partly transfer the management of state-owned forests to private businesses. This could be supported by a number of reasons. One of them relates to market deregulation, transparency and international capital mobility (OECD, 2018b).

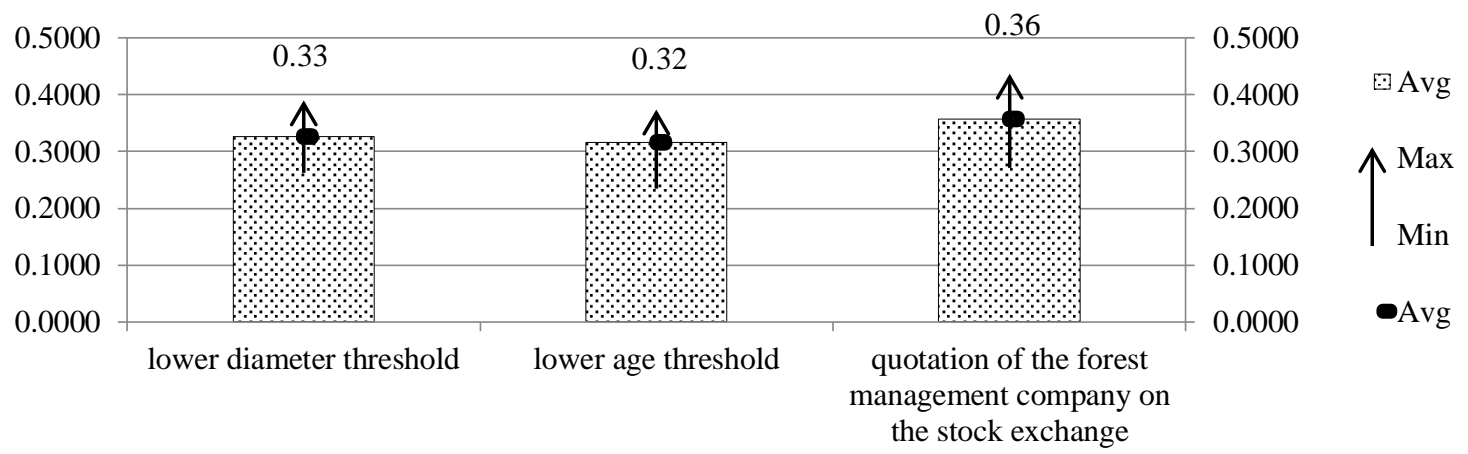

Source: authors calculation based on Analytical Hierarchy Process, 2019

Figure 3. Experts' ratings of the potential scenarios for enhancement of forest management 
As shown in Figure 3, the highest average rating was 0.36, which was given by the experts to the scenario of full or partial transfer of the management of state-owned forests to private businesses; it was followed by the scenario of lowering the diameter threshold for felling trees with 0.33 , while the scenario of lowering the age threshold for felling trees was rated the lowest, at 0.32 . The arrows in Figure 3 show the range of ratings - the shorter the arrow, the lower the dispersion of ratings. It was observed that the experts' ratings of the scenario of full or partial transfer of the management of state-owned forests to private businesses had higher dispersion. This reduces the unambiguity of the result. Nevertheless, one can overall conclude that quite similar ratings were given to all the scenarios for enhancement of forest management, and policy makers could consider all the options to enhance forest management in Latvia.

\section{Calculations of NPV for the selected scenarios}

Compared with the effects made by change in age or diameter threshold for felling trees, the discount rate makes the largest effect on the value of forest capital. The higher the discount rate, the lower the value of forest capital. The availability of cheaper capital abroad, which could lower the discount rate, might arouse interest in investment in forests in Latvia. The JSC LSF currently uses a discount rate of $4.58 \%$ (JSC LSF, 2018). An ambiguous conclusion could be made if comparing a private company and a state-owned company - the state-owned company has a higher credit rating, which results in lower borrowed capital costs. At lower borrowed capital costs, which is specific to the state-owned company, the value of forest capital is higher. Consequently, the privatisation of the state-owned company would lower the value of forest capital. However, if the private investor represents a country having a higher credit rating, where the investor's company has a higher credit rating than Latvia has, the investor could pay more for forestland than domestic private companies or the national government value the forestland. For this reason, the scenario for enhancement of forest management that was rated the highest by the experts - quotation of the JSC LSF on the stock exchange and full or partial transfer of the state-owed forest management company to private ownership - leads to the lowest value of forest capital, compared with the other two scenarios, at any discount rate (Figure 4). Besides, the relevant legal acts being in force do not envisage the privatisation of the JSC LSF.

A comparative analysis of NPV for the potential scenarios for enhancement of forest management revealed: lowering the diameter threshold for felling trees by two centimetres raises the value of forest capital more than lowering the age threshold by ten years does. Accordingly, making amendments to the relevant legal framework to lower the diameter threshold by at least two centimetres is preferable to lowering the age threshold if the goal is to raise the value of forest capital. At the same time, both scenarios could be introduced simultaneously.

The NPV calculated is not comparable with the value of forest capital estimated by the JSC LSF because the authors have no accurate information on the methodology employed by the JSC LSF. Nevertheless, the NPV calculated by the authors indicates a trend to be considered in assessing the three scenarios for enhancement of forest management.

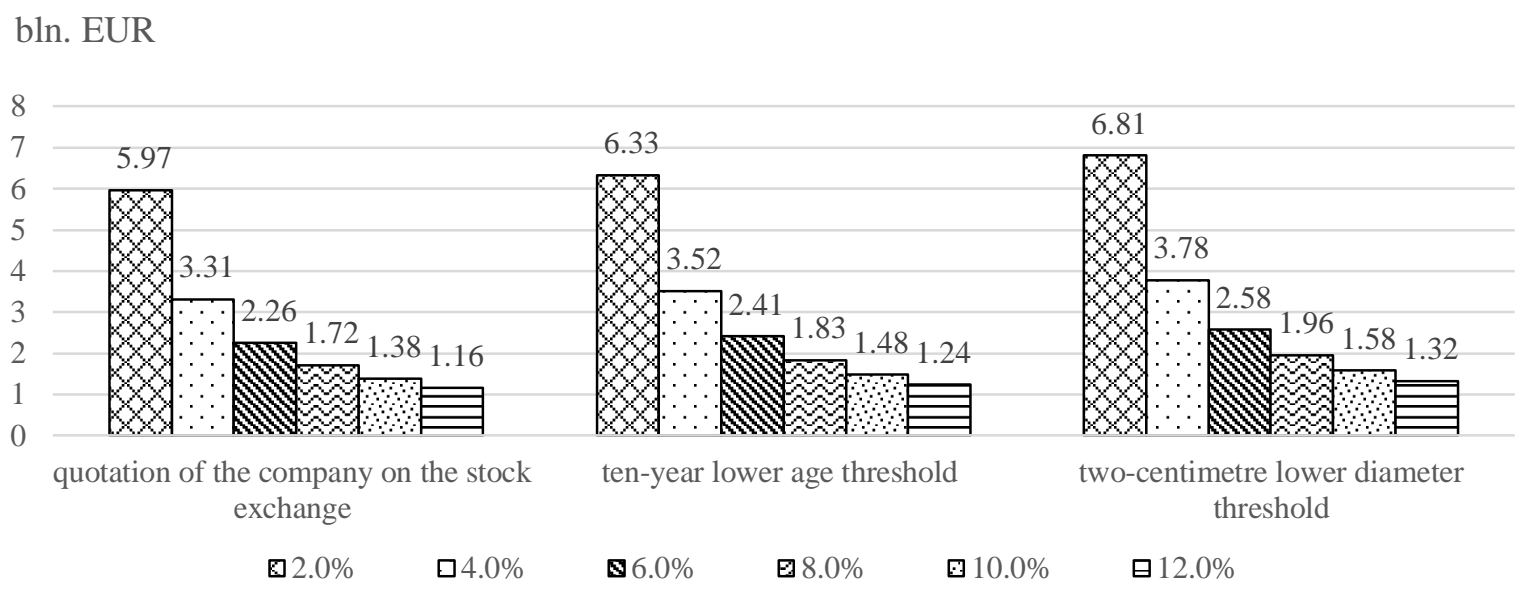

Source: authors' calculations, 2019

Figure 4. Results of calculating of the value of forest capital for the three scenarios, billion EUR

The highest value of forest capital for all the three potential scenarios could be found at the lowest discount rate $-2 \%$, which is consistent with a suggestion made by V.Brukas et al. (2001) that an optimum discount rate for sustainable forest management is in the range of $0-2 \%$. Accordingly, the scenario of full or partial transfer of state-owed forests to private ownership through quoting the company's shares on the stock exchange should be considered in a long-term and, perhaps, at lower discount rates. It is particularly important in case it involves foreign capital.

\section{CONCLUSIONS}

1) The experts gave quite similar ratings to all the scenarios for enhancement of forest management. The scenario of quoting the forest management company's shares on the stock exchange had the highest average rating $(0.36)$, yet the dispersion of the experts' ratings was the highest as well. The scenario of lowering the diameter threshold for felling trees had the second highest average rating (0.33), followed by the scenario of lowering the age threshold for felling trees with a slightly lower average rating (0.32). Implementing any of the scenarios requires making amendments to the relevant legal framework. 
2) The analysis of the potential scenarios for enhancement of forest management by NPV, using different discount rates with an increment of two percentage points, revealed that lowering the diameter threshold for felling trees by two centimetres would raise the value of forest capital more than lowering the age threshold by ten years. The scenario of quotation of the forest management company on the stock exchange leads to the lowest NPV of forest capital, compared with the other scenarios. Besides, the highest value of forest capital for all the scenarios were found at the lowest discount rate of $2 \%$. If the goal of enhancing forest management involves raising the value of forest capital, it is required to make amendments to the relevant legal framework to lower the diameter threshold for felling trees.

3) One can conclude that it is necessary to perform a more detailed examination of the discount rate used for identifying the value of forest capital.

Acknowledgement: The research study was funded by the grant "Strengthening Research Capacity in Latvia University of Life Sciences and Technologies", project No. Z38.

\section{REFERENCES}

1. Bekeris P. 2011. Latvia's Forest During 20 Years of Independence. Publishing by BALTI Group, 46 p.

2. Buongiorno J. 2001. Quantifying the implications of transformation from even to uneven aged forest stands. Forest Ecology and Management, No. 151, pp. 121-132. https://doi.org/10.1016/S0378-1127(00)00702-7

3. Brukas V., Thorsen B.J., Helles F., Tarp P. 2001. Discount rate and harvest policy: Implications for Baltic forestry. Forest Policy and Economics, No 2, pp. 143-156. https://doi.org/10.1016/S1389-9341(01)00050-8

4. CSP 2019. IKG10_010. Total gross domestic product, per capita and per person employed. Available at: http://data1.csb.gov.lv/pxweb/lv/ekfin/ekfin_ikp_IKP_ikgad/IKG10_010.px/

5. Faustmann M. 1995. Calculation of the value which forest lad and immature stands possess for forestry. Reprinted in Journal of Forest Economics, Vol. 1, pp. 7- 44 from the original: Berechnung des Wertes welchen Waldboden sowie noch nicht haubare Holzbestände für die Waldwirtschaft besitzen, Allgemeine Forst- und Jagdzeitung, vol. 15.

6. European Commission 2019. EU forestry explained, Available at: https://ec.europa.eu/info/food-farming-fisheries/forestry/forestryexplained

7. Jacobsen J.B., Helles F. 2006. Adaptive and non-adaptive harvesting in uneven-aged beech forest with stochastic prices. Forest Policy and Economics, Vol. 8(3), pp. 223-238. https://doi.org/10.1016/j.forpol.2004.06.004

8. Jacobsen J.B., Vedel S.E., Thorsen B.J. 2013) Assessing costs of multifunctional NATURA 2000 management restrictions in continuous cover beech forest management. Forestry, Vol. 85(5), pp. 575-582. https://doi.org/10.1093/forestry/cpt023

9. Jacobsen J.B. Jensen F., Thorsen Bo. (2016). Forest Value and Optimal Rotations in Continuous Cover Forestry. Environmental and Resource Economics., Vol. 69, pp. 713-732 https://doi.org/10.1007/s10640-016-0098-Z

10. Joint stock company Latvian State Forests (JSC LSF). Annual report 2018, 46 p.

11. Cabinet of the Republic of Latvia 1999. Decision No. 453 of 24 September 1999 "On the Establishment of the State Joint stock company Latvian State Forests", Riga. Available at: https://likumi.lv/doc.php?id=17919

12. Law on Forests of the Republic of Latvia . 2000. Available at: https://likumi.lv/doc.php?id=2825

13. Liepa I. 1996. Pieauguma mācība. Latvijas Lauksaimniecibas Universitāte (Growing Stock Increase Theory, Latvia University of Agriculture), 123 p. (In Latvian)

14. Liaison Unit Bratislava. 2018. Enhancing the Long-term Competitiveness of the Forest Sector in a Green Economy: Policies for Forest-based Bioeconomy in Europe. 29 May 2018, Brussels Workshop Report, 12 p. Available at: https://foresteurope.org/wpcontent/uploads/2017/08/Workshop-report_final-1.pdf

15. Navarro G.A. 2003. Re-examining the theories supporting the so-called Faustmann Formula. In: Helles F., Strange N. and Wichmann, L., Recent accomplishments in applied forest economics research forestry sciences. Kluwer Academic Publishers, Dordrecht, pp. 19-38. https://doi.org/10.1007/978-94-017-0279-9 2

16. Newman D.H. 2002. Forestry's golden rule and the development of the optimal forest rotation literature. Journal of Forest Economics, Vol.8, pp. 5-27. https://doi.org/10.1078/1104-6899-00002

17. Ohlin B. 1921. Till frågan om skogarnas omloppstid. Ekonomisk Tidsskrift, No. 22, pp. 89-113. Reprinted as Ohlin B. (1995). Concerning the question of the rotation period in forestry. Journal of Forest Economics, Vol. 1 (1), pp. 89-114. https://doi.org/10.2307/3472369

18. Organization for Economic Cooperation and Development (OECD) (2018a) Global Material Resources Outlook to 2060 Economic drivers and environmental consequences. Available at: https//global-recycling.info/archives/2906

19. Organization for Economic Cooperation and Development (OECD) (2018b). Privatisation and the Broadening of Ownership of State-Owned Enterprises Stocktaking of National Practices, 84 p. Available at: https://www.oecd.org/daf/ca/Privatisation-and-the-Broadening-ofOwnership-of-SOEs-Stocktaking-of-National-Practices.pdf

20. Pressler, M. R. 1860. ‘Aus der Holzzuwachlehre (zweiter Artikel)', Allgemeine Forst und Jagd Zeitung, vol. 36, pp. 173-191. Translated by W. Löwenstein and J. R. Wirkner (1995) as 'For the comprehension of net revenue silviculture and the management objectives derived thereof', Journal of Forest Economics, Vol. 1, No. 1, pp. 45-87.

21. Pukkala T., Kolström T. 1988. Simulation of the development of Norway Spruce stands using a transition matrix. Forest Ecology and Management, Vol. 25, pp. 255-267. https://doi.org/10.1016/0378-1127(88)90091-6

22. Saaty T. 1990. How to make a decision: The analytic hierarchy process. European Journal of Operational Research, Vol. 48, Iss. 1, pp. 9-26. https://doi.org/10.1016/0377-2217(90)90057-I

23. Södra 2018. Annual Report 2018, 2 p. 
24. Samuelson P.A. 1995. Economics of forestry in an evolving society. Reprinted in: Journal of Forest Economics, Vol.1, pp.115-149. https://doi.org/10.1111/j.1465-7295.1976.tb00437.x

25. Ministry of Agriculture of the Republic of Latvia. 2015. Guidelines for the Development of Forestry and Related Industries 20152020, 69 p.

26. State Forest Service. 2018. Wood volumes logged, mln.m³ , Available at: https://www.vmd.gov.lv/valsts-meza-dienests/statiskas-lapas/meza-apsaimniekosana-/koksnes-resursu-ieguve?nid=1682\#jump 